Michele De Beni*

ORCID: 0000-0001-9440-4804

Loppiano, Włochy

\title{
Mistrz jako wzór życia i myślenia
}

\section{The Teacher as a Model of Life and Thought}

\begin{abstract}
Summary: The present article focuses on pedagogical aspects emerging from Chiara Lubich's written work and oral conversations. Here, three major points are elaborated: the importance of the relationship as a fundamental element of education; the importance of the educational model, conceptualised as the need of an Ideal Teacher source of life inspiration; the concept of thought and knowledge as a service of love to the world. Points of conversation were fostered within the framework of these aspects to develop a model upon which education, thought and action are built as means of fraternal service.
\end{abstract}

Keywords: educator; model; knowledge; thought; service.

Streszczenie: Celem artykułu jest ukazanie pedagogicznych aspektów zawartych w niektórych przemówieniach i pismach Chiary Lubich. Przedmiotem niniejszej refleksji są trzy zasadnicze zagadnienia: prymat relacji - jako konstytutywny

* Michele De Beni, pedagog i psychoterapeuta; profesor pedagogiki personalistycznej i pedagogiki wspólnoty w Instytucie Uniwersyteckim Sophia (Istituto Universitario „Sophia”) w Loppiano k. Florencji; wykładowca w Centrum Studiów Międzykulturowych na Uniwersytecie w Weronie (Centro Studi Interculturali dell'Università di Verona). Koordynator ze strony Włoch Międzynarodowego projektu Co.R.T. (Cort Thinking), kierowanego przez Edwarda 
aspekt wychowania; znaczenie wzoru wychowawczego - rozumianego jako zapotrzebowanie na Ideał Mistrza, który może być inspiracją dla wychowanka; znaczenie poznania i myślenia - rozumianych jako służenie z miłości do świata. W kontekście przedstawionych zagadnień usiłuje się poszerzyć horyzonty dyskusji na temat modelu ukazującego sens wychowania, myślenia i działania jako braterskiego służenia.

Słowa kluczowe: mistrz; wychowawca; wzór; poznanie; myślenie; służenie.

Zbliżenie się do postaci tak szlachetnej i odważnej jak Chiara Lubich po to, aby ukazać zastosowanie niektórych aspektów jej charyzmatu w obszarze wychowania, jest przede wszystkim przywilejem, ale także trudnym wyzwaniem na płaszczyźnie badań naukowych. Z pedagogicznego punktu widzenia jest to okazja, aby rozważyć nadzwyczajną aktualność świadectwa jej życia i myśli, przede wszystkim w perspektywie zaproszenia do podjęcia wyzwania wciąż aktualnego - a zarazem zawsze nowego - na gruncie wychowawczym. Z pomocą tak wyjątkowego świadka pragnę ukazać, przynajmniej syntetycznie, kilka zasadniczych zagadnień, m.in. to, które dotyczy postaci Mistrza oraz zdolności myślenia, przywołując wrażenie, jakie wzbudziła we mnie lektura niektórych pism mistyczki.

\section{Wychowanie jako powołanie do milości}

Na wstępie odwołam się do zasadniczej przesłanki stanowiącej podstawę dyskursu pedagogicznego: życie Chiary Lubich było wiernym odbiciem jej słów i przekonań. Właśnie to, ważniejsze wobec innych kwestii, jest fundamentem całego dyskursu i praktyki edukacyjnej. Istotnie, jak podkreślił Paweł VI, „człowiek naszych czasów chętniej słucha świadków aniżeli nauczycieli; a jeśli słucha nauczycieli, to dlatego, że są świadkami"'. Teoria-Praktyka, Myśl-Działanie, Słowo-Życie. Tak autentycznego świadectwa młodzi oczekują od dorosłych, wezwanych do spajania słów z doświadczeniem, ideałów z konkretnym, codziennym zaangażowaniem. Tylko w ten

de Bona. Kontakt: Istituto Universitario Sophia, Via San Vito n. 28, Loppiano, 50064 Figline e Incisa Valdarno (FI), Włochy (www.sophiauniversity.org/it); e-mail: debeni.m@gmail.com.

${ }^{1}$ Paweł VI, Adhortacja Evangelii Nuntiandi (Watykan, Libreria Editrice Vaticana, 1975), $\mathrm{nr} 41$. 
sposób mistrz może być autentyczny, może rozwijać potencjał wychowanka i ukierunkowywać go ku dobru.

Podczas jednego ze spotkań z mieszkańcami Loppiano² w 1971 r. Lubich podejmuje temat świadectwa, łącząc je z powołaniem w jego podwójnym znaczeniu: z jednej strony jako „powołanie”, „wybór”, „,pasja”, „pociąg" ku pewnemu Ideałowi, zapalonemu w sercu przez Boga, a z drugiej strony jako „poświęcenie”, „uczucie” wobec braci. Jest to nieopisywalna wrażliwość, jakiej Lubich doświadczyła już jako młoda nauczycielka ${ }^{3}$ - zachęcona silną społeczną i wychowawczą pasją, zdolną nadać sens nadziei na dobre życie - w szkole Mistrza jej głębi [życia wewnętrznego], który wezwał ją do całkowitego podarowania się $\mathrm{Mu}$, w miłości do braci, także tych najmniejszych, zmarginalizowanych, niekochanych, z ,tych wszystkich ludzkich i społecznych rzeczywistości i doświadczeń, w których szczególnie widać naglącą potrzebę wychowania"4.

Moim zdaniem otwiera się tutaj interesująca i bardzo aktualna perspektywa na to, co uważam za istotny jakościowo aspekt wychowania - nieustanne wyzwanie ,prymatu relacji”, co odczuwała i czym żyła Chiara Lubich: troska o relacje między ludźmi, aby zrozumieć ich motywacje i oczekiwania, lęki, sprzeczności i pragnienia, aby dotrzeć do ich serca i otworzyć umysły. Jest to lekcja, którą dobrze byłoby przyjąć dzisiaj za podstawową w „szkole autentycznie wychowującej”: ludzie i wspólnoty zwróceni nie na skuteczność, lecz na więzi, które stanowią istotną treść stosunków międzyludzkich i społecznych dla ,idealnego miasta”, nadającego życiu sens i spójność. W takim świetle widać, że poważny kryzys, który dotyka współczesną edukację, jest nie tyle metodologiczny, ile aksjologiczny. Innymi słowy, nie jest to kryzys narzędzi, ale kryzys wartościowych treści. Nie tyle chodzi tu o ,jak”, ale o „dlaczego”, o wybór i uzasadnienie proponowanych celów.

\section{Mistrz jako wzór}

Z punktu widzenia Lubich wychowanie może być postrzegane w bezpośrednim związku ze świadectwem o własnym powołaniu, rozumianym nie jako prosty akt komunikatywny i relacyjny, lecz jako akt miłości, dar

2 Chiara Lubich, „Gesù Maestro”, Nuova Umanità 6 (2008): 607-612.

${ }^{3}$ Por. Quando la scuola educa, red. Michele De Beni (Roma: Città Nuova, 2017).

${ }^{4}$ Chiara Lubich, Charyzmat jedności, red. Michel Vandeleene (Kraków: Fundacja Mariapoli, Wydawnictwo M, 2007), 317. 
ofiarowany w wolności, na wzór wychowawczego modelu Jezusa. Stoimy zatem przed koniecznością wprowadzenia pojęcia pedagogicznego modelu transcendentalnego, metawychowawczego, nie abstrakcyjnego, lecz czytelnie ukazanego w postaci Mistrza-świadka; życia, które wychowanek obserwuje i przyjmuje jako inspirację dla swoich zachowań. Można tu przywołać całą preśredniowieczną chrześcijańską tradycję pedagogiczną, która odwołuje się do Bożej Pedagogii, do „pedagoga” par excellence - Boga, który wskazuje drogę do Prawdy. W takim ujęciu wymiar Boży ożywa i łączy się z wymiarem ludzkim ${ }^{5}$. Rzeczywistość i utopia, praktyka i ideał, u Lubich przyjmują charakter spójnego doświadczenia życiowego, ukierunkowanego na postać Jezusa: Mistrza i Wzór. Nie jest to przyjmowanie jakiegoś wzoru abstrakcyjnego, zalecanego przez Kościół, lecz opartego przede wszystkim na osobistym doświadczeniu autentycznego i ożywczego - usytuowanego w historii - spotkania z Osobą Jezusa, z Jego żywą obecnością pośród „dwóch lub trzech zebranych w Jego imię" (Mt 18,20). W tym sensie jest On prawdziwym Mistrzem ${ }^{6}$, ponieważ dzięki swojemu nauczaniu przewodzi, wspiera i ukierunkowuje. Jednocześnie jest Wzorem, gdyż na fenomenologicznej i empirycznej podstawie doświadczeń przeżytych osobiście oraz przez osoby, które naśladowały ten sposób życia, Lubich i jej pierwsze towarzyszki mogą potwierdzić, bo dostrzegały to codziennie, jak niezwykle „zbawienne” dla ludzkości są skutki tego Wzoru w życiu osobistym, rodzinnym, społecznym, ekonomicznym i kulturalnym. W świetle tego Wzoru wychowanie nie jest interpretowane jako zwyczajna prawda objawiona, lecz jest ono poddane na bieżąco refleksji, w rzetelnej dyskusji pedagogicznej z uwzględnieniem stosownych badań i wyjaśnień na płaszczyźnie racjonalnej . Śladem tej

5 Por. Klemens Aleksandryjski, Wychowawca, thum. Marian Szarmach (Toruń: Wydawnictwo Naukowe Uniwersytetu Mikołaja Kopernika, 2012).

${ }^{6}$ Pojęcie prawdziwego Mistrza może być stawiane w opozycji do oszałamiającego antropocentrycznego postmodernizmu, wymagającego otwartości na sformułowania, które nie są związane wyłącznie z filozofią praktyczną, lecz kierują się ku nowym wyżynom, na dowolne „objawienie” przychodzące z zewnątrz - od kogoś innego niż ja sam - po transcendentny wymiar życia. „Prawdziwy Mistrz” może odnosić się też do „wartości”, a zatem kogoś, kto jest godny uznania za ważnego, szanowanego, gdyż wyraża takie cechy charakterystyczne jak: wartość samego siebie w propagowaniu ideałów; wartościową rzeczywistość dla życia osobistego i społecznego; podmiotowe wybory, które zakładają odpowiedzialne działanie kompromisowe; dobra kulturowe, będące punktem odniesienia danego narodu, kultury.

7 Pierwotny tytuł Proslogion Anzelma z Aosty brzmiał: Wiara, która szuka zrozumienia (Fides quarens intellectum) [Por. Anzelm z Aosty, „Proslogion”, tłum. Leszek Kuczyński, Przegląd Tomistyczny 3 (1987): 179]. Dla pełniejszego obrazu zagadnień wychowawczych 
prawdy jest bliskość Boga w obliczu drugiego człowieka, w bracie. W tym sensie twarz drugiego jest dowodem na obraz Nieskończonego, który jest w każdej istocie ludzkiej, dzięki mniej lub bardziej świadomej relacji, jaką każdy człowiek ma z Bogiem. Uaktualnia się ona właśnie w tej konkretnej relacji z drugim. Ten drugi jest zatem drogą dojścia do Innego, Nieskończonego w samym sobie, celu ostatecznego, ale także pośrednikiem samej relacji między ludźmi ${ }^{8}$.

\section{Mistrz życia i myślenia}

O ile postać Jezusa Mistrza jako wzoru ma bez wątpienia kluczowe znaczenie dla pedagogicznej analizy pism i przemówień Chiary Lubich, to sądzę, że kolejnymi zasadniczymi elementami, którym Lubich przypisuje znaczenie i wartość, są: poznanie [wiedza] i myśl. Proste, lecz wymowne potwierdzenie tego można znaleźć w świadectwach jej uczniów ze szkoły podstawowej ${ }^{9}$. W udzielonym wywiadzie stwierdzają, że jednym z najbardziej wymagających i powtarzających się pytań ich nauczycielki - gdy stawali wobec jakiegoś problemu, wątpliwości lub konieczności wydobycia i zrozumienia innego punktu widzenia - było jednoznaczne pytanie: „Ale co ty o tym sądzisz?". Było to prowokacyjne zaproszenie do dialogu, aby pomóc temu drugiemu zadać sobie pytanie, spróbować wyjaśnić, postawić jakąś hipotezę rozwiązania, a tym samym wziąć na siebie odpowiedzialność za własną myśl. Istotnie, człowiek młody, uczeń, będzie na tyle dobrze wyszkolony i kompetentny, na ile będzie zdolny do systematycznej refleksji nie tylko dotyczącej jego sposobu uczenia się, ale także tego, jak radzi sobie z każdym aspektem życia osobistego, społecznego i kulturalnego.

„Ale co ty o tym myślisz?" - to może być przewodnia linia metody ukierunkowanej na bezpośrednią odpowiedzialność ucznia, przede wszystkim w zakresie poszukiwań, zarówno osobistych, jak i kulturowych. W tym

podejmowanych przez ojców Kościoła oraz wielkich teologów średniowiecza warto zapoznać się z pracami Giuseppego Groppa [zob. Giuseppe Groppo, „Teologia dell'educazione”, w: Enciclopedia pedagogica, t. VI (Brescia: La Scuola, 1994), 11787-11798].

${ }^{8}$ Por. Emmanuel Lévinas, O Bogu, który nawiedza myśl, tłum. Małgorzata Kowalska (Kraków: Znak, 1994).

9 Donato Chiampi, „La maestra Silvia non aveva la matita rossa”, w: Essere educatori, coraggio di una presenza, red. Michele De Beni (Roma: Città Nuova, 2014). DVD - Wywiad $\mathrm{z}$ byłymi uczniami. 
sensie wychowawca nie wypowiada się ex cathedra, aby nauczać, indoktrynować, lecz aby przedstawić określoną „wersję” swojego punktu widzenia. Jego zadaniem nie jest ani ukrywanie problemu, ani jakaś standaryzacja, lecz zaproszenie do podejmowania drogi i doprowadzenia różnych punktów widzenia do jedności ${ }^{10}$, stymulując $\mathrm{w}$ ten sposób potencjał i kreatywne zaangażowane uczniów, włączonych $\mathrm{w}$ akt poznania i myślenia, postrzeganego w swej istocie jako proces współwychowawczy. Mistrz, jako idealny wzór nadający kierunek działaniom wychowawczym, oraz ćwiczenie się w myśleniu - postrzeganym jako praktyczne i spekulatywne działanie - mogą być wyrazem continuum, w którym spójnie łączą się ze sobą Ideał i Życie.

\section{Poznawanie i myślenie z miłości}

Możemy postawić sobie pytanie o znaczenie i rolę, jakie Lubich nadaje poznawaniu, myśleniu i ich wzajemnym relacjom z określonym Wzorem pedagogicznym, który dla Chiary Lubich jest tożsamy z Osobą Jezusa. Lubich, przemawiając do mieszkańców miasteczka Loppiano, odnosi się do tego następująco:

skoro Loppiano jest szkołą, skoro pełni funkcję szkoły, to jednak jest to szkoła bardzo szczególna i oryginalna. W rzeczywistości to nie książki, sale lekcyjne, studia są tym najważniejszym, co sprawia, że jest to szkoła. Nie, Loppiano jest szkołą, ponieważ tu jest Mistrz. To On dał założycielom inspirację co do założeń tego miasteczka, sposobu jego powstania i rozwoju. On jest też Tym, który żyje wśród mieszkańców tego miasta. Wiemy, że tym, który zainspirował istnienie tego miasta i mieszka wśród jego mieszkańców, jest Jezus ${ }^{11}$.

Sokrates, zmagając się z typowym dla swoich czasów dekadenckim sposobem myślenia, odnosi się do myśli jako świadectwa prawdy i jako lekarstwa (pharmacon) przeciwko złu życia. Tylko boskość jest mądra, a wiedza ludzka jest warta niewiele lub nic; jeżeli zatem ktoś uważa, że ma wiedzę i wyobraża sobie, że ma wiedzę absolutną, w rzeczywistości porzuca prawdziwe poznanie. Dlatego człowiek musi przede wszystkim rozpoznać swoją własną ograniczoność. Jeśli więc wiedza jako „wiedza dla bytu” pochodzi

${ }_{10}$ Por. Maria Zambrano, Chiari nel bosco (Milano: Feltrinelli, 1991).

${ }^{11}$ Lubich, „Gesù”, 607-612. 
z uznania własnej ograniczoności, to jaki jest jej fundament, prawdziwy sens, prawda, do której należy dążyć? ${ }^{12}$

Wzorcowa odpowiedź z pewnością pochodzi z tekstu Chiary Lubich „Jezus Mistrz"13. Dyskurs przybiera tutaj charakterystyczną strukturę argumentacyjną: nie tyle stara się opisać rzeczywistość, ile ją zrozumieć w jej zasadniczym wymiarze. Proponuje ona myślenie nie tylko o rzeczywistości, ale też o pełni rzeczywistości, włączając w obserwowanie ,zasadę transcendencji”, która pozwala wyjść poza „zasadę oczywistości”14. Dlatego myślenie nie jest rozumiane tylko jako logiczno-naukowa opcja prawdy, ale raczej jako pewność ducha, a zatem jako wewnętrzne zrozumienie. Nie wyklucza ono bynajmniej badań i wyjaśnień związków przyczynowych, ale uzasadnia ich znaczenie w wymiarach wartości.

Dlatego należy uściślić, że ta opcja, tak zdecydowanie wyrażona w kierunku transcendentnego modelu poznania, ukazana dla chrześcijan przez życie i nauczanie Jezusa, nie może być rozumiana jako istota rzeczy zdefiniowana a priori, ale jako prawdziwa i właściwa praca badawcza, w ścisłym związku pedagogiki istnienia (wł. pedagogia dell'esistenza) z pedagogiką istoty (wł. pedagogia dell'esenza) ${ }^{15}$. W takim ujęciu Jezus jako człowiek-Bóg skupia w sobie cechy rzeczywistości i utopii, czasowości i transcendencji ${ }^{16}$. Faktycznie, kiedy Lubich odnosi się do miasta jako do szkoły ży-

12 Jak stwierdza Edgar Morin, zrozumienie opiera się również na poczuciu skończoności i ograniczeniach, jest to etyka zrozumienia ,zorientowana na tolerancję. W istocie, jeśli przed potępieniem będziemy umieli zrozumieć, wejdziemy na ścieżkę humanizowania relacji międzyludzkich" [Edgar Morin, I setti saperi necessari all'uomo futuro (Milano: Cortina, 2001), 104]. Istotne poglądy o sensie ludzkich ograniczeń znajdujemy w tradycji monastycznej, w której „modlenie się” łączone jest nie tylko z adoracją, lecz także z „prośbą”, prośbą o objawienie się prawdy. „W zdaniu się na objawienie się Absolutu mnich nakreśla ścieżkę myślenia”, która nie jest adaptacją do logiczno-syntaktycznej poprawności, lecz do prawdziwego znaczenia prawdy [Carlo Scilironi, In cammino verso l'uomo (Milano: S. Paolo, 1994), 24].

13 Lubich, „Gesù”, 607-612.

${ }^{14}$ Edmund Husserl przestrzegał przed niebezpieczeństwem utraty sensu współczesnej wiedzy. Ma to istotne znaczenie zwłaszcza na płaszczyźnie wychowania, dla którego wiedza powinna być priorytetowym celem. [Por. Edmund Husserl, Idea fenomenologii, thum. Janusz Sidorek (Warszawa: PWN, 2014), 77, 81; por. Carlo Nanni, L'educazione tra crisi e ricerca di senso (Roma: Libreria Ateneo Salesiano, 1986)].

15 Por. Bodgan Suchodolski, Pedagogia dell'essenza e pedagogia dell'esistenza (Roma: Armando, 1965); Maurice Debesse, Gaston Mialaret, Trattato delle scienze pedagogiche, t. 1 (Roma: Armando, 1971), 99.

${ }^{16} \mathrm{~W}$ świetle takiego modelu, kierunku myśli, wychowanie jest postrzegane nie tyle jako potoczna prawda, lecz powinno być analizowane zgodnie ze współczesnymi wymaganiami 
cia - oryginalnej dlatego, że szkołą czynią ją nie typowe dla tych instytucji książki, sale lekcyjne, uczenie się, ale obecność Mistrza „Jezusa z jego bardzo szczególnymi lekcjami, które nie mają nic wspólnego nawet z największymi nauczycielami świata" 17 - to nie zamierza dewaluować nauczania ani uczenia się. Zarówno człowiek, jak i Jezus są mistrzami, choć w różnych formach i na różnych poziomach: człowiek uczy prawd ograniczonych, przypadkowych, potwierdzanych przez rozum, podczas gdy Jezus Mistrz naucza prawd uniwersalnych, które przemawiają do sumienia. A to - kontynuuje Lubich - może być postrzegane przez nawet najmądrzejszych ludzi jako „nauka, która jest głupotą”, tzn. nauka „nieracjonalna”, ponieważ nie skupia się wyłącznie na argumentach rozumowych. I to właśnie jest kluczowym aspektem dyskursu Lubich: tu następuje otwarcie się na wiedzę - mądrość ${ }^{18}$, niesprzeczną z dowodami ani z badaniami psychologicznymi i społecznymi, lecz zawierającą je, a zarazem przekraczającą, jako „nauka o świadomości”. Horyzont rozszerza się i wznosi ponad granice, których postmodernistyczna myśl, skupiona tylko na sobie, zdaje się nie potrafić przekroczyć. Zaproszenie Jezusa, które Lubich rozumie jako wezwanie do ,pozostawienia nauczycieli" i podążania za Jego nauczaniem ${ }^{19}$, może być odczytywane jako podjęcie tematu dotyczącego relacji pomiędzy wiedzą i mądrością. Poszukiwanie pierwotnego źródła sensu staje się dominującym motywem, kwestią hierarchicznego wyboru, w którym znaczenie pojawia się przed samym przedmiotem poznania. To Jezus nadaje kształt wszystkim innym znaczeniom. On jest Nieskończonym Sensem, który ogarnia różne skończone znaczenia. W takim ujęciu „ofiarowanie wszystkich prawd, które ludzie mogą nam dać”, nie

stawianymi przez pedagogikę, obejmującymi także stosowne badania oraz racjonalne wyjaśnienia [por. Anselmo d'Aosta, Proslogion (Milano: Rizzoli BUR, 2012), 1, 27 (1077); Anzelm z Aosty, „Proslogion”. 179].

17 Lubich, „Gesù”, 607-612.

18 „Odwołujemy się tutaj do dobrze znanego związku i rozróżnienia między mądrością a inteligencją. Jak twierdzą najbardziej reprezentatywni badacze nauk kognitywistycznych, trzeba zająć się myślą, która prowadzi do mądrości, a nie tą, która determinuje inteligencję. W gruncie rzeczy, jeśli staniesz się mądry, nie jest tak trudno stać się inteligentnym. Jeśli zamiast tego zaczniemy od bycia inteligentnym, nie mamy nadziei na mądrość, ponieważ bardzo łatwo wpaść w «pułapkę» inteligencji” [Edward De Bono, Io ho ragione, tu hai torto (Milano: Sperling e Kupfer, 1990)].

19 Zauważalna jest tutaj głęboka spójność duchowa pomiędzy Chiarą Lubich i św. Augustynem, a bardziej pedagogiczna z Klemensem z Aleksandrii, oboje zafascynowani postacią Chrystusa, Pana i Pedagoga Ludzkości. Tak też jest w pismach Romana Guardiniego o pedagogice chrześcijańskiej [por. Romano Guardini, Persona e libertà (Brescia: La Scuola, 1987), 24]. 
wymaga wyrzeczenia się ich czy też odrzucenia koniecznej autonomii badań naukowych, opartych na własnych celach i metodach. Jest to raczej ponowna kontekstualizacja znaczenia, która nie mieści się w nauce jako takiej ${ }^{20}$.

Ujawnia się tu jedno z zasadniczych uwarunkowań pedagogicznych, jakim jest „wymiar teleologiczny”, widziany nie w jego formalnej abstrakcji, lecz przyjęty w typowej dla niego dialektyce, pojmowanej w znaczeniu chrześcijańskim, pomiędzy człowiekiem-światem a człowiekiem-cnotą. Nie ma tu więc miejsca na wyznaczanie, jak w tradycji arystotelesowskiej, celów etyczno-politycznych czy humanistyczno-retorycznych, lecz istotne jest budowanie fundamentów natury transcendentnej, których zasadniczą treścią jest Słowo Boże. Jest to także zapowiedź bardzo wzniosłej koncepcji pedagogicznej, której etos wyraża się w Nowym Przykazaniu miłości wzajemnej (J 13,34), co gwarantuje - jak wspomina Lubich - obecność Tego, który żyje i wzbudza życie wśród mieszkańców rodziny, szkoły, miasta, społeczności i szeroko rozumianej kultury.

\section{Myśleć - służyć}

Zaproszenie Jezusa zostało więc wyjaśnione: „Nie chciejcie również, żeby was nazywano mistrzami, bo jeden jest tylko wasz Mistrz" (Mt 23,10). Jezus oczywiście nie twierdzi, że wspólnota nie potrzebuje nauczycieli, lecz że potrzebuje przede wszystkim świadków życia ukierunkowanych na Niego, który jest Miłością. Myślenie jest zatem prawdziwe, jeśli nie skupia się na samym sobie, ale umie stać się myślą exodalną, jeśli zamiast monologu potrafi stać się opowiadaniem: o sobie dla samego siebie i o sobie dla innych; oraz jeśli potrafi stać się dialogiem: z własnym światem wewnętrznym oraz ze światem społecznym i kulturowym.

Tak rodzi się wspólnota badawcza, bardzo odmienna od współczesnej „wspólnoty naukowców”21. Przypomina ona raczej wspólnotę „badawczą”, która z całą pewnością nie rezygnuje ze ścisłych praw racjonalności (krytycznego myślenia), odkrywczego rozwoju i wyobraźni (twórczego myślenia), ale opiera się na poczuciu przynależności i współdzieleniu, co łączy członków tej wspólnoty ze sobą, oraz na myśli wyrażonej w zainteresowa-

${ }^{20}$ Nawet współczesny paradygmat ekologiczny wypracował wyraźną świadomość ograniczenia metody obiektywnej [por. Luigina Mortari, Epistemologia della ricerca pedagogica (Verona: Universitaria, 2003), 31-36].

${ }^{21}$ Matthew Lipman, Educare al pensiero (Milano: Vita e Pensiero, 2000). 
niu drugim. Rzeczywiście, jak przekonuje Jezus w Ewangelii św. Mateusza $(23,11)$ : „Największy z was niech będzie waszym sługą”; Jezus zachęca do używania rozumu nie jako władzy człowieka nad człowiekiem, lecz jako drogi wzajemnej odpowiedzialności. Prosi o wyrzeczenie się władzy, nie jako wyrzeczenie się myślenia, lecz jako wybór nie rządzenia, lecz służenia ${ }^{22}$.

Myślenie, jeżeli jest wyrazem miłości, może więc stać się prawdziwym aktem służby dla człowieka, dla ludzkości. $Z$ tej zasady wzajemnej miłości bierze swój początek zarówno budząca szacunek, demokratyczna postawa wychowawcy - jako aktywny proces współuczestniczenia - jak również koncepcja ciągłej formacji, angażującej zarówno wychowanka, jak i wychowawcę, nawet jeżeli tempo i poziom tego procesu są różne, w cyklicznym procesie wspólnej wymiany i dążenia w kierunku ,powinności”. To tutaj mistrz urzeczywistnia podwójny wymiar nauczyciela i ucznia: nie jest to dychotomia, ale spójna całość, która $\mathrm{z}$ jednej strony musi być skonfrontowana z codziennym działaniem edukacyjnym i osobą wychowanka, z drugiej zaś z poszukiwaniem sensu i celami życia.

Jezus nie zbudował więc jakiejś doktryny, tzn. teorii, ale raczej świadczył swoim życiem o prawdach, o których mówił i w które wierzył. Stąd jego nauczanie może dezorientować, jeśli będzie przyrównywane do struktur, które przyjęły język i metody badań racjonalnych. W takim ujęciu może się też ono wydawać niewarte uwagi, jakoby nienaukowe, a przecież z fenomenologicznego punktu widzenia nie możemy zakładać, że to doświadczenie jest sprzeczne z nauką. Wręcz przeciwnie, pod pewnymi względami antycypuje ono wyniki, ponieważ istnienie i istota są współobecne. Rzeczywiście, istnienie stanowi konkretne określenie istoty. Życie Jezusa, którego istotny wymiar stanowi także jego nauczanie, nie jest w żaden sposób sprzeczne z możliwością przełożenia go na praktykę edukacyjną, a zatem empirycznie, na badanie oraz weryfikację faktów i wyników. W związku z tym można postawić hipotezę Modelu, który na podstawie refleksji teologicznych może być racjonalnie zaprezentowany i zgodny zarówno z punktu widzenia kulturowego, jak i naukowego.

Można zatem stwierdzić, że jeśli Jezus Mistrz może być rozumiany według wzorca teologicznego i empirycznego, to może dać początek nowym i przekonującym hipotezom w badaniach pedagogicznych, które przyczyniają się do powstania teorii również pod względem poznawczym.

${ }^{22}$ Jak wyraża to dobitnie Carlo Scilironi: „władza bez możności rządzenia jest służeniem” [Scilironi, In cammino, 115]. 


\section{Myśleć - być nicością z milości}

Możemy postawić sobie pytanie, w jaki sposób przełożyć myśl na akt miłości. Jest to dynamika, która łączy w sobie życie i myśl, teorię i praktykę, osobisty proces badawczy oraz dialog. Jest to proces słuchania, daru i komunii, takiego myślenia, które jest współuczestniczeniem, wprowadzeniem przez Syna Jezusa w przestrzeń i logikę Trójcy Świętejej. W tej logice Jezus na krzyżu, wołając: „Boże mój, Boże mój, czemuś Mnie opuścił?” (Mt 27,46), jest ,szczytem” miłości, ,punktem kulminacyjnym, najpiękniejszym wyrazem miłości”"24, a także „cudem rezygnacji z tego, co jest”. Słuszne jest zatem przekonanie, że myśl jest owocna, jeśli jest „uwolniona od siebie [pustką w sobie]"25. Owo ,nic" [pustka] nie jest tu rozumiane jako przeciwieństwo istnienia, ale jako istnienie-miłość. W różnych „lekcjach” Chiary Lubich pojęcia nicości, daru i miłości są ściśle powiązane, a w „Jezusie Opuszczonym” odnajdują swój najwyższy wyraz, symbol ekstremalnej miłości: Jezusa, który jest Wszystkim, który staje się Nicością z miłości ${ }^{26}$.

Jest to ta sama logika, która powinna przemieniać myślenie, które, przeniknięte miłością, staje się jedno z miłością. W ten sposób - z miłości - tracę mój sposób myślenia, odsuwam go, uciszam, aby uchwycić bogactwo myśli i to wszystko, co jest w drugim. Dopiero taka zmiana może prowadzić do konstruktywnej, dynamicznej syntezy, jest w stanie przezwyciężyć rozdrobnienie i przyjąć różnorodność nauk ${ }^{27}$ : cel nie jest łatwy i prosty, ale kierując się nim, autentyczny wychowawca powinien osobiście i we wspólnocie wziąć odpowiedzialność, aby odnaleźć odwagę wychowywania, otworzyć

${ }^{23}$ O koncepcji Trójcy Świętej widzianej z perspektywy Jezusa Opuszczonego, Piero Coda pisze: „Bóg jest Bytem «stając się», w Sobie Innym od Siebie: umierając w Sobie, jak Ojciec, «będąc» (rodząc) Syna, i «odnajdując Siebie» w Koinonii-wolności, którą jest Duch. Boska Istota Boga jest zatem wszystkim jedynie w dynamice jego życia «międzyosobowego», w którym każda z Trzech Osób jest Bogiem, Jedynym, w tym, że «nie jest», w tym, że «daje siebie», w tym, że daje to, co jest najbardziej jego, Bycie Bogiem" [La Trinità e il pensare, red. Piero Coda, Andreas Tapken (Roma: Città Nuova, 1997), 15].

${ }^{24}$ Chiara Lubich, „Mistero d'amore”, Gen 18 (1984): 3.

${ }^{25}$ Chiara Lubich, „Conversazione ai focolarini (8.12.1971)” [cyt. za: Judith Povilus, Gesù in mezzo nel pensiero di Chiara Lubich (Roma: Città Nuova, 1981), 83].

${ }^{26}$ Dla pogłębienia koncepcji „nicości” i ,jednoczenia się z miłości” zob.: Hubertus Blaumeiser, „Un mediatore che è Nulla”, Nuova Umanità 117-118 (1998): 385-407.

${ }_{27}$ Piero Coda, „Alcune riflessioni sul conoscere teologico”, Nuova Umanità 122 (1999): 191-206. 
oczy nasze i młodych ludzi na nowe przestrzenie prawdziwej inteligencji. Bez wątpienia zostaje tu wprowadzony istotny element, odnoszący się do „metody”, dzięki której wychowanek może podążać drogą swojej pełnej realizacji: miłości do brata. Efektem tej metody jest pełnia radości, szczęście, które wymaga umiejętności życia w „postawie wzajemnego widzenia Jezusa w drugim" 28 , wcielonej obecności Mistrza jako podstawy więzi jedności między osobami (a więc także między wychowawcą a wychowankiem, pomiędzy wychowankami i pomiędzy wychowawcami), związanymi paktem wzajemnej miłości. Z tego powiązania motywów teoretycznych i doświadczenia wynika, że proces wychowania jest możliwy, nie jest abstrakcyjną utopią, ale odważnym, codziennym wychodzeniem naprzeciw oraz poszukiwaniem „nieba gwiaździstego nade mną i prawa moralnego we mnie" 29 .

Ttumaczenie: Stanistaw Grochmal, Mariola T. Kozubek, Matgorzata Radomska

\section{Bibliografia}

Anzelm z Aosty. „Proslogion”, thum. Leszek Kuczyński. Przegląd Tomistyczny 3 (1987): 179-216.

Blaumeiser, Hubertus. „Un mediatore che è Nulla”. Nuova Umanità, 3-4 (1998): 385-407.

Chiampi, Donato. „La maestra Silvia non aveva la matita rossa”. DVD - Wywiad z jej uczniami. W: Essere educatori, coraggio di una presenza (Być wychowawca, odwaga obecności), red. Michele De Beni. Roma: Città Nuova, 2014.

Coda, Piero. „Alcune riflessioni sul conoscere teologico”. Nuova Umanità 122 (1999): 191-206.

Conferenza Episcopale Italiana. Orientamenti Pastorali. Educare alla vita buona del Vangelo. Milano: Edizioni S. Paolo, 2010.

Debesse, Maurice, Gaston Mialaret. Trattato delle scienze pedagogiche, t. 1. Roma: Editore Armando, 1971.

De Bono, Edward. Io ho ragione, tu hai torto. Milano: Sperling e Kupfer, 1990.

${ }^{28}$ Tu jest też racja bytu edukacji, która nie może ignorować wymiaru etycznego, historycznie i teleologicznie uzasadnionego [por. Alasdair MacIntyre, Dziedzictwo cnoty. Studium $z$ teorii moralności, tłum. Adam Chmielewski (Warszawa: PWN, 1996)].

${ }_{29}$ Por. Immanuel Kant, Krytyka praktycznego rozumu, thum. Benedykt Bornstein (Kęty: ANTYK, 2002), 158. 
Groppo, Giuseppe. „Teologia dell'educazione”. W: Enciclopedia pedagogica, t. VI, 11787-11798. Brescia: Editrice La Scuola, 1994.

Guardini, Romano. Persona e libertà. Brescia: Editrice La Scuola, 1987.

Husserl, Edmund. Idea fenomenologii, thum. Janusz Sidorek. Warszawa: PWN, 2014.

Kant, Immanuel. Krytyka praktycznego rozumu, tłum. Benedykt Bornstein. Kęty: ANTYK, 2002.

Klemens Aleksandryjski. Wychowawca, thum. Marian Szarmach. Toruń: Wydawnictwo Naukowe Uniwersytetu Mikołaja Kopernika, 2012.

La Trinità e il pensare, red. Piero Coda, Andreas Tapken. Roma: Città Nuova, 1997.

Lévinas, Emmanuel. O Bogu, który nawiedza myśl, tłum. Małgorzata Kowalska. Kraków: Znak, 1994.

Lipman, Matthew. Educare al pensiero. Milano: Editrice Vita e Pensiero, 2000.

Lubich, Chiara. Charyzmat jedności, red. Michele Vandeleene. Kraków: Fundacja Mariapoli, Wydawnictwo M, 2007.

Lubich, Chiara. „Gesù Maestro”. Nuova Umanità 6 (2008): 607-612.

Lubich, Chiara. „Mistero d'amore”. Gen 18 (1984): 3.

MacIntyre, Alasdair. Dziedzictwo cnoty. Studium z teorii moralności, tłum. Adam Chmielewski. Warszawa: PWN, 1996.

Morin, Edgar. I setti saperi necessari all'uomo futuro. Milano: Edizioni Cortina, 2001.

Mortari, Luigina. Epistemologia della ricerca pedagogica. Verona: Editrice Universitaria, 2003.

Nanni, Carlo. L'educazione tra crisi e ricerca di senso. Roma: Libreria Ateneo Salesiano, 1986.

Quando la scuola educa, red. Michele De Beni. Roma: Città Nuova, 2017.

Paweł VI. Adhortacja Evangelii Nuntiandi. Watykan: Libreria Editrice Vaticana, 1975.

Povilus, Judith. Gesù in mezzo nel pensiero di Chiara Lubich. Roma: Città Nuova, 1981.

Scilironi, Carlo. In cammino verso l'uomo. Milano: Edizioni S. Paolo, 1994.

Suchodolski, Bodgan. Pedagogia dell'essenza e pedagogia dell'esistenza. Roma: Editore Armando, 1965.

Zambrano, Maria. Chiari nel bosco. Milano: Editrice Feltrinelli, 1991. 
